\title{
Antigenic Cross-reactivity of Major Outer Membrane Proteins in Enterobacteriaceae Species
}

\author{
By H. HOFSTRA AND J. DANKERT \\ Laboratory for Medical Microbiology, State University Groningen \\ and Division of Hospital Infections, University Hospital A.Z.G., \\ Groningen, Oostersingel 59, The Netherlands
}

(Received 25 July 1978)

\begin{abstract}
The protein constituents in the outer membrane (OM) of several serotypes of Escherichia coli and some other Enterobacteriaceae cross-reacted antigenically. Solubilized OM preparations of these bacteria were applied in interfacial precipitin tests to antisera elicited in rabbits against whole bacterial cells, absorbed with their appropriate lipopolysaccharide before testing. The resulting immunecomplexes were analysed on polyacrylamide gels. Protein profiles of the immunoprecipitates showed a considerable antigenic cross-reactivity of outer membrane proteins between most $E$. coli serotypes. Cross-reactivity, though substantially lower, was also found with OM from three other Enterobacteriaceae species, but was not detectable with Pseudomonas aeruginosa OM. When OM preparations were solubilized at room temperature, the peptidoglycan-bound proteins in the molecular weight range 37000 to 41000 predominated in the protein profiles of the immunecomplexes. In profiles of immunecomplexes obtained with boiled OM preparations, a heat-modifiable protein (mol. wt 33000) predominated. The major OM proteins of the Gram-negative bacterium may therefore play a role as common surface antigens of the family of Enterobacteriaceae.
\end{abstract}

\section{INTRODUCTION}

The outermost envelope of Gram-negative bacteria consists of the outer membrane and lipopolysaccharide (LPS). The immunology of the LPS of the Enterobacteriaceae has been thoroughly investigated, especially the somatic or $\mathrm{O}$ antigen. Antibodies against this heatstable antigen have agglutinating properties and give type-specific protection (Tate et al., 1966; Ziegler et al., 1973). Another antigenic structure found in most Gram-negative bacteria is the flagellar or $\mathrm{H}$ antigen. In some organisms, like Escherichia coli and Klebsiella pneumoniae, there is a third antigen, $\mathrm{K}$ antigen, which represents a polysaccharide capsule exterior to the outer membrane. Antibodies against the $\mathrm{K}$ antigen protect only against homologous organisms (Kaijser \& Ahlstedt, 1977). Since antisera against these diverse antigens provide only strain-specific protection, workers have searched for cross-reacting bacterial antigens. The common antigen described by Kunin et al. (1962) is well known, but immune response to this antigen differs in patients with various enterobacterial infections (Neter et al., 1973), and McCabe \& Greely (1973) failed to demonstrate protective activity of antibodies to this antigen in experimental infections. Another antigen shared by most Gram-negative rods is the so-called inner core, which links the $\mathrm{O}$ antigen of the LPS to the lipid A moiety buried in the outer membrane layer. The protective value of antibodies against the inner core of LPS is controversial. Chedid et al. (1968), Ziegler et al. (1973) and McCabe et al. (1977) demonstrated their beneficial effect against infections caused by different Gram-negative strains. However, $\mathrm{Ng}$ et al. (1976) found no protection in mice challenged with heterologous strains, probably due to inaccessibility of the immunodeter- 
minants. Young et al. (1975) concluded that antibodies against this shared structure act primarily as antitoxins rather than as opsonins and that they provide no enhancement of blood stream clearance. Antibodies against lipid A, which has a similar structure in most Gram-negative rods, have been described (Galanos et al., 1971), but they lack protective activity (Mullan et al., 1974; McCabe et al., 1977). One of the major protein components of the outer membrane of Gram-negative bacteria has been described as a common antigen by Braun et al. (1976). The protective value of this antigen is questionable since in wildtype strains it may be shielded by other membrane components. The immunogenicity of the other proteins of the outer membrane has been reported (Dankert \& Hofstra, 1978). Comparison of polyacrylamide gel electrophoretic protein profiles of the outer membranes of some Enterobacteriaceae species reveals certain similarities (Schnaitman, 1970; Lugtenberg et al., 1977) suggesting that outer membrane proteins may form common antigens.

In this study, we have investigated the antigenic cross-reactivity of outer membrane proteins in some E. coli serotypes, three related Enterobacteriaceae species and Pseudomonas aeruginosa.

\section{METHODS}

Bacterial strains and growth conditions. Escherichia coli, serotypes $01 \mathrm{~K}^{-}, 04 \mathrm{K2}, 026 \mathrm{~K} 60$, $055 \mathrm{~K} 59$ and $075 \mathrm{~K}^{-}$, were isolated in our laboratory. Escherichia coli $\mathrm{O} 111 \mathrm{~K} 58$ and its galactose epimerasedeficient mutant strain J5 were a gift from Dr B. Witholt, Laboratory of Biochemistry, State University, Groningen. All strains of E. coli and the Salmonella typhimurium strain were serotyped by the Rijksinstituut voor de Volksgezondheid, Bilthoven, The Netherlands. Klebsiella pneumoniae, Proteus vulgaris and Pseudomonas aeruginosa were isolated and identified in our laboratory according to Cowan \& Steel (1965). Bacteria were grown in 101 flasks under vigorous aeration at $37^{\circ} \mathrm{C}$ in a liquid medium containing $\left(\mathrm{g} \mathrm{l}^{-1}\right.$ in deionized water): $\mathrm{Na}_{2} \mathrm{HPO}_{4}, 7 \cdot 5 ; \mathrm{KH}_{2} \mathrm{PO}_{4}, 3 ; \mathrm{NaCl}, 0.5 ; \mathrm{NH}_{4} \mathrm{Cl}, 0.1 ; \mathrm{MgSO}_{4} .7 \mathrm{H}_{2} \mathrm{O}, 0.25 ; \mathrm{CaCl}_{2} .2 \mathrm{H}_{2} \mathrm{O}, 0.0015$; yeast extract, 10; and glucose, 5. The pH was adjusted to 7.4. Escherichia coli strain $\mathrm{J} 5$ was grown on essential salts medium (Vogel \& Bonner, 1956) with glycerol as a carbon source.

Isolation of outer membrane. Bacteria were grown for $3 \mathrm{~h}$ to late-exponential phase and harvested by centrifugation $\left(8000 \mathrm{~g}, 15 \mathrm{~min}, 4^{\circ} \mathrm{C}\right.$ ). They were sheared in a homogenizer (MSE) for $1 \mathrm{~min}$ in $0.05 \mathrm{M}$ Tris/ $\mathrm{HCl}$ buffer ( $\mathrm{pH} 7 \cdot 8)$ containing 1 mM-EDTA to remove extracellular materials, and then disintegrated by repeated passage through an X-press (Nike, Eskilstuna, Sweden). Outer membranes (OM) were obtained after Triton X-100 (Sigma) extraction of the crude membrane fraction (Schnaitman, 1971).

Isolation of lipopolysaccharides. Bacteria were grown overnight in glucose broth, harvested $(8000 \mathrm{~g}$, $15 \mathrm{~min}$ ) and dried with acetone. LPS was prepared by phenol/water extraction (Westphal et al., 1952). The aqueous phase was dialysed against demineralized water $\left(48 \mathrm{~h}, 4^{\circ} \mathrm{C}\right)$, concentrated to approximately $50 \mathrm{ml}$ in a rotary evaporator (Bühler, Tübingen, Germany) and finally lyophilized. Preparations were stored at $4{ }^{\circ} \mathrm{C}$ until used. Protein content was estimated according to Lowry et al. (1951). 2-Keto-3-deoxyoctonate was determined by the thiobarbituric acid method (Ellwood, 1970).

Preparation of antisera. For each bacterial strain, two rabbits were injected intravenously with formaldehyde-fixed cells. Each rabbit received four doses, increasing from $0.5 \times 10^{9}$ to $2 \times 10^{9}$ cells, over 2 weeks. Rabbits were bled 1 week after the final injection. Samples $(10 \mathrm{ml})$ of the sera were stored without preservative at $-20^{\circ} \mathrm{C}$.

Absorption of antisera. Antibodies directed against bacterial LPS were removed from the sera by stepwise addition of a concentrated solution containing the appropriate crude LPS $\left(10 \mathrm{mg} \mathrm{m}^{-1}\right.$; not freed from nucleic acids; protein content less than $5 \%(\mathrm{w} / \mathrm{w})$ in the Lowry assay, OM proteins not detectable by polyacrylamide gel electrophoresis). Usually about $1.5 \mathrm{mg}$ was added to $1 \mathrm{ml}$ antiserum. The absence of antibodies against LPS was tested by interfacial immunoprecipitation tests with the antigen dissolved in $0.9 \%(\mathrm{w} / \mathrm{v}) \mathrm{NaCl}$ (Kwapinski, 1972) and by immunodiffusion in agarose.

Agglutination tests. These were done as previously described (Dankert \& Hofstra, 1978).

Immunoprecipitin tests. Antigenic solutions were prepared by solubilization of OM in sodium dodecyl sulphate (SDS) at room temperature or at $100{ }^{\circ} \mathrm{C}$. At room temperature, $\mathrm{OM}$ samples were dispersed in phosphate-buffered saline (PBS) containing $0.2 \%$ (w/v) SDS followed by sonication (10 to $20 \mathrm{~s}, 50 \mathrm{~Hz}$; Branson Ultrasonics, Soest, The Netherlands). In the other procedure, samples were boiled for $5 \mathrm{~min}$ in PBS containing $2 \%(\mathrm{w} / \mathrm{v})$ SDS, then diluted with PBS to $0.2 \%(\mathrm{w} / \mathrm{v})$ SDS. The final OM concentration in both preparations was $1 \mathrm{mg} \mathrm{ml}^{-1}$. The cross-reactivity of SDS-solubilized OM proteins as antigenic components of the Gram-negative envelope was determined in interfacial immunoprecipitin tests with antiserum against $E$. coli $\mathrm{O} 26 \mathrm{~K} 60$ (Dankert \& Hofstra, 1978). In addition, OM of E. coli $\mathrm{O} 26 \mathrm{~K} 60$ was 
reacted with each of the antisera elicited against the bacterial strains used in this study. Pre-immunization sera of all rabbits used for the preparation of antisera were applied as controls. All antisera were absorbed with their specific LPS before use in immunoprecipitin tests to exclude the possibility of cross-reacting LPS. SDS was added to the antisera to a final concentration of $0 \cdot 15 \%(\mathrm{w} / \mathrm{v})$. Immunoprecipitates were sedimented $\left(20 \mathrm{~min}, 10000 \mathrm{~g}, 4{ }^{\circ} \mathrm{C}\right.$ ), washed three times with $0.9 \%(\mathrm{w} / \mathrm{v}) \mathrm{NaCl}$ containing $0.15 \%(\mathrm{w} / \mathrm{v}) \mathrm{SDS}$ and stored at $-20^{\circ} \mathrm{C}$ until analysed on polyacrylamide gels.

SDS-polyacrylamide gel electrophoresis. This was carried out according to Laemmli (1970) on slab gels as described by Ames (1974). Staining, destaining and photography of the gels, as well as the application of standard proteins for molecular weight estimation, were described by Dankert \& Hofstra (1978).

\section{RESULTS AND DISCUSSION}

\section{Outer membrane proteins of several Gram-negative bacteria}

The major protein complex of the outer membranes (OM) of seven strains of $E$. coli was resolved by polyacrylamide gel electrophoresis (PAGE) into distinct protein bands with apparent molecular weights ranging from 33000 to 41000 (Fig. 1, tracks 1 to 7 ). Three or, sometimes, four bands could be seen in this region. Lugtenberg et al. (1975) were able to resolve the major OM proteins of $E$. coli $\mathrm{K} 12$ into four bands (a, b, c and d). Bands b and c represent protein I of Henning et al. (1973), while band $d$ is the heatmodifiable protein, described as protein $\mathrm{II}^{*}$ by Garten et al. (1975). A band moving like protein a, Schnaitman's protein 3B (Manning \& Reeves, 1977), was seen in the profiles of strain $\mathrm{J} 5$ and serotypes $\mathrm{O} 111 \mathrm{~K} 58, \mathrm{O} 4 \mathrm{~K} 2$ and $\mathrm{O} 75 \mathrm{~K}^{-}$. The protein b band was usually rather faint, though visible in all strains when OM preparations were applied to the gels in small amounts. Protein c was present in the PAGE profiles of all strains, while protein $\mathrm{d}$ was visible as a dense band in all profiles except that from $E$. coli $\mathrm{O} 1 \mathrm{~K}^{-}$. The profile of this serotype showed a protein band (mol. wt about 35000) which was not observed in the profiles of the other strains. Proteins III (mol. wt 16000) and IV (mol. wt 7500) of Henning et al. (1973) were present in the OM fractions of all strains, but the bands were very weak in the profile of strain $\mathrm{J} 5$.

Profiles of OM fractions of strains of Salmonella typhimurium, Klebsiella pneumoniae, Proteus vulgaris and Pseudomonas aeruginosa are also shown in Fig. 1 (tracks 8 to 11). The profile of $S$. typhimurium OM (Fig. 1, track 8) was similar to that described by Ames (1974). The electrophoretic mobility of the most pronounced band was similar to that of band $\mathrm{b}$ in the $E$. coli strains. In the major protein region of the profile of OM from $K$. pneumoniae (Fig. 1, track 9) two bands with apparent molecular weights of 39000 and 34000 were seen. These bands had similar electrophoretic mobilities to proteins $b$ and $d$ of $E$. coli. The OM profile of Proteus vulgaris showed bands corresponding to molecular weights of 38000 and 41000 (Fig. 1, track 10) coinciding with proteins c and a of E. coli. A weaker band moved like the 35000 dalton protein band of $E$. coli $\mathrm{O} 1 \mathrm{~K}^{-}$. The profiles of $S$. typhimurium and $K$. pneumoniae $\mathrm{OM}$ showed a protein band in the molecular weight region of 15000 to 16000 possibly resembling protein III in the E. coli patterns. Lipoprotein was not detected in amounts comparable to those in most $E$. coli strains.

Thus OM protein profiles of different enterobacterial strains had common features, as described by Schnaitman (1970) and Lugtenberg et al. (1977). However, the similarity was much more evident between the strains of one species $(E$. coli) than between strains of different species in the family of Enterobacteriaceae. In membrane fractions of Pseudomonas aeruginosa, extracted by Triton X-100 and analysed by PAGE, at least six proteins with molecular weights ranging from 18000 to 50000 were seen (Fig. 1, track 11). This profile was unlike any of the enterobacterial OM protein patterns. 


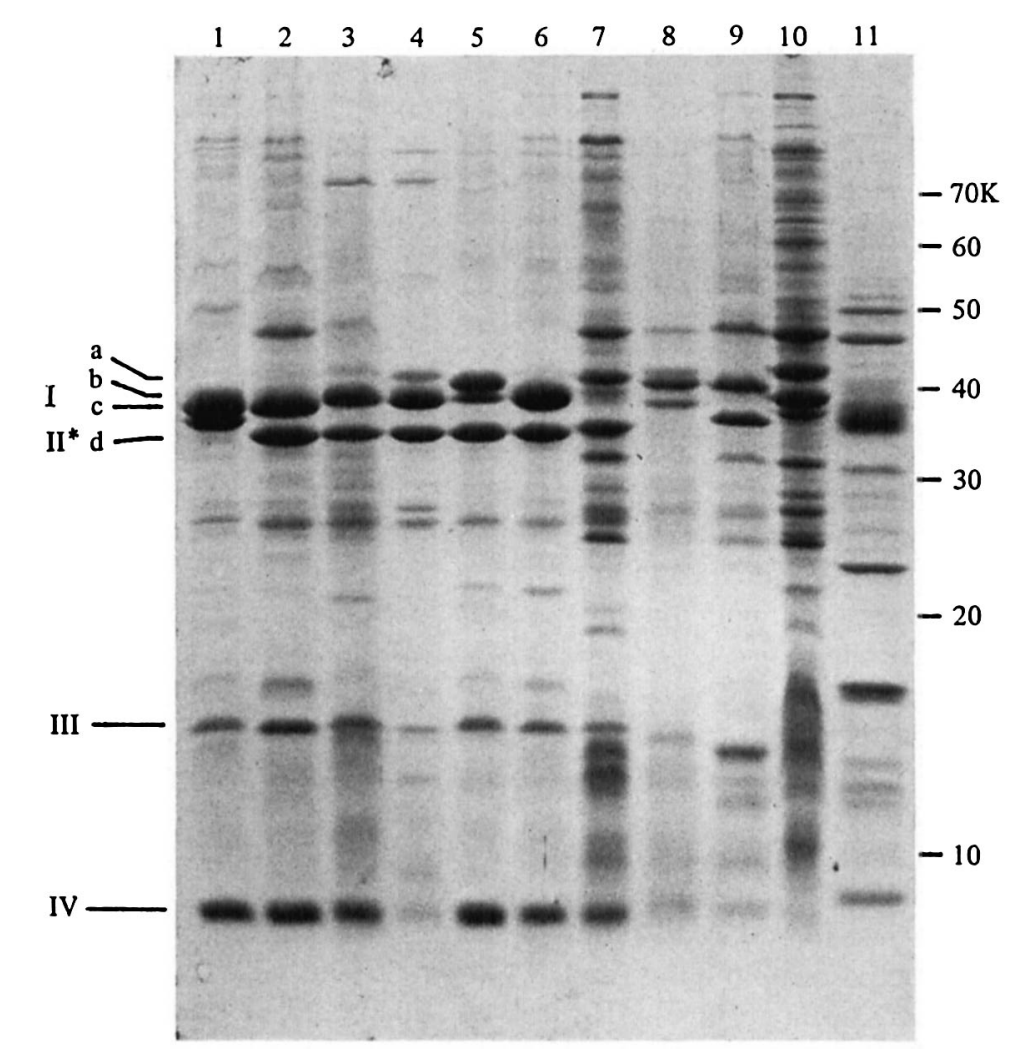

Fig. 1. Polyacrylamide gel electrophoresis patterns of outer membrane preparations of $E$. coli serotypes $01 \mathrm{~K}^{-}$(1), O26 K60 (2), O111 K58 (3), strain J5 (4), O4 K2 (5), O55 K59 (6), O75 K(7), Salmonella typhimurium (8), Klebsiella pneumoniae (9), Proteus vulgaris (10), Pseudomonas aeruginosa (11). On the left, proteins are designated I to IV after Henning et al. (1973) and a, b, $\mathrm{c}$ and $\mathrm{d}$ after Lugtenberg et al. (1975). Molecular weights are indicated on the right.

\section{Polyacrylamide gel electrophoresis of immunecomplexes from antiserum against \\ E. coli $\mathrm{O} 26 \mathrm{~K} 60$ and outer membrane preparations of Gram-negative bacteria}

Cross-reactivity between $\mathrm{OM}$ proteins was determined in interfacial precipitin tests with OM fractions, solubilized in SDS at room temperature or at $100{ }^{\circ} \mathrm{C}$, and rabbit antiserum prepared against $E$. coli $\mathrm{O} 26 \mathrm{~K} 60$, absorbed with its appropriate LPS. After LPS absorption the bacterial agglutination titre of this antiserum had decreased from 1:8000 to $1: 64$. OM preparations of most $E$. coli serotypes gave clearly visible precipitin rings resembling those observed with $E$. coli $\mathrm{O} 26 \mathrm{~K} 60 \mathrm{OM}$, though those for $K$. pneumoniae and Proteus vulgaris were weak. $\mathrm{OM}$ of $E$. coli $\mathrm{O} 1 \mathrm{~K}^{-}, S$. typhimurium and Pseudomonas aeruginosa gave insignificant precipitin rings.

PAGE profiles of repeatedly washed immunoprecipitates formed with OM preparations solubilized at room temperature showed the presence of albumin, the heavy and light chains of rabbit immunoglobulins and some of the major OM proteins (Fig. 2). Crossreactivity with the $\mathrm{OM}$ proteins of the $E$. coli strains (except $\mathrm{O} 1 \mathrm{~K}^{-}$) was greater than with the three other Enterobacteriaceae species and there was no apparent cross-reactivity with $P$. aeruginosa OM. Peptidoglycan-associated proteins $\mathrm{b}$ and $\mathrm{c}$ were more evident than the heat-modifiable protein d (Fig. 2, tracks 3 to 8). In the immunecomplexes obtained with $\mathrm{O} 4 \mathrm{~K} 2$ and $\mathrm{O} 75 \mathrm{~K}^{-} \mathrm{OM}$, the 41000 dalton protein gave a dense band. The 16000 dalton protein and lipoprotein (mol. wt 7500) were visible in the PAGE profiles of immunecomplexes of most $E$. coli strains when gels were freshly stained. 


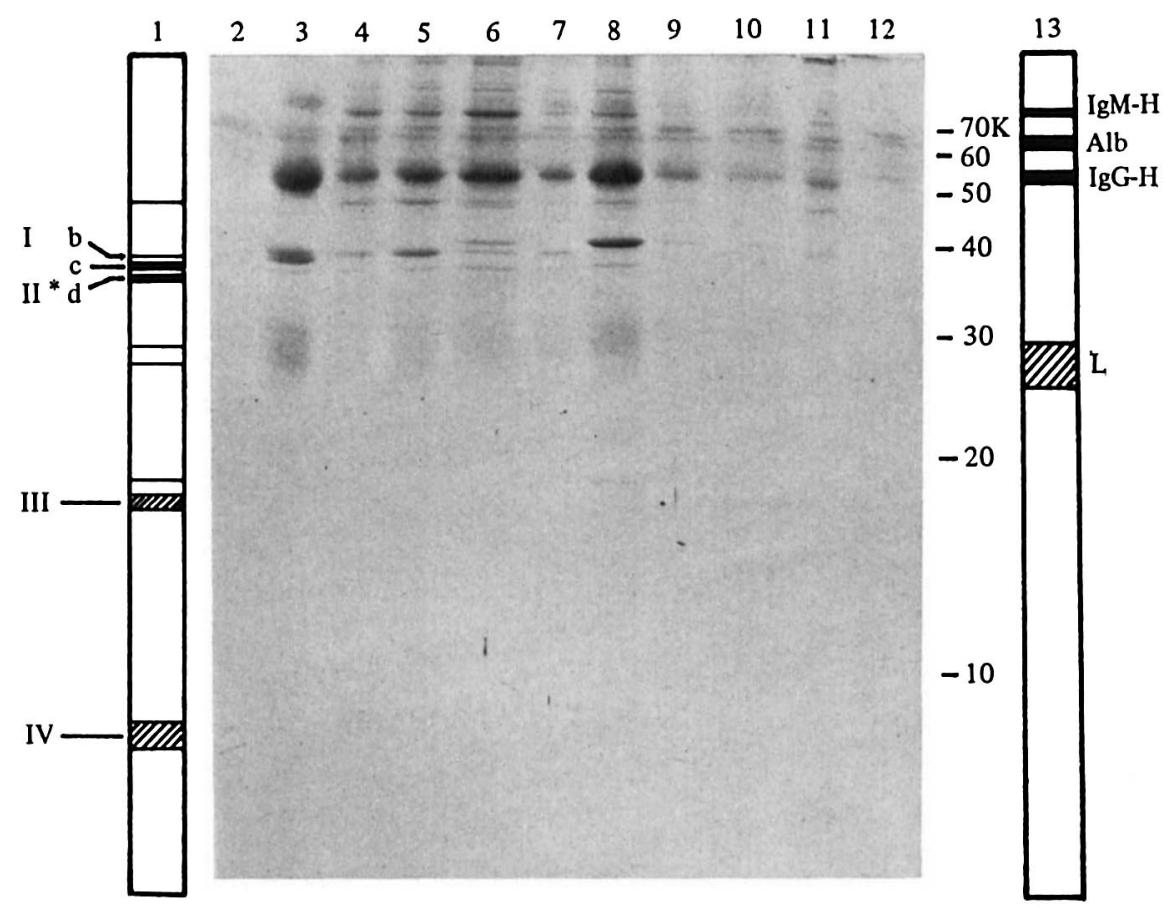

Fig. 2. Polyacrylamide gel electrophoresis patterns of immunoprecipitates obtained in interfacial precipitin tests carried out with antiserum against $E$. coli O26 K60 (absorbed with LPS O26) containing $0.15 \%(\mathrm{w} / \mathrm{v})$ SDS and outer membrane preparations of several Gram-negative bacteria, solubilized in $0.2 \%(\mathrm{w} / \mathrm{v}) \mathrm{SDS}$ at room temperature: $E$. coli serotypes $\mathrm{O} 1 \mathrm{~K}^{-}(2), \mathrm{O} 26 \mathrm{~K} 60(3)$, O111 K58 (4), strain J5 (5), O4 K2 (6), O55 K59 (7), O75 K- (8); Salmonella typhimurium (9); Klebsiella pneumoniae (10); Proteus vulgaris (11); Pseudomonas aeruginosa (12). A control gel of the OM of E. coli O26 K60 is shown on track 1 (protein designations as in Fig. 1). Non-microbial bands in the immunoprecipitates correspond to heavy and light chains of rabbit immunoglobulins and albumin, as indicated by a control gel (13): IgM-H, heavy chains of IgM; Alb, albumin; IgG-H, heavy chains of IgG; L, light chains.

Figure 3 shows protein profiles of immunecomplexes formed after reaction of OM preparations solubilized in boiling SDS, with anti-O26 K60 serum. Rabbit immunoglobulin bands were present in all profiles, although for E. coli $\mathrm{O} 1 \mathrm{~K}^{-}$and Pseudomonas aeruginosa these were very weak. Bands of OM proteins could be seen in most profiles. The precipitate resulting from the reaction between $\mathrm{OM}$ of $E$. coli $\mathrm{O} 26 \mathrm{~K} 60$ and the antiserum against this strain contained the OM proteins with a marked predominance of protein d over proteins b and c (Fig. 3, track 3). This predominance was also seen in most other profiles (Fig. 3, tracks 4 to 8 and 10). Bands in the molecular weight range of proteins a, b and c of $E$. coli OM (36000 to 41000$)$ were seen in most profiles, but were only visible for a short time after gel-destaining.

The results presented in Figs 2 and 3 indicated cross-reactivity of the major OM proteins of the E. coli strains and of three related Enterobacteriaceae species. The difference between protein profiles of immunoprecipitates obtained with antigens solubilized at room temperature (Fig. 2) and at $100^{\circ} \mathrm{C}$ (Fig. 3) was probably caused by the degree to which the OM components were solubilized as polymolecular structures or as separate molecules. At room temperature, $0 \cdot 2$ to $2 \%(\mathrm{w} / \mathrm{v})$ SDS only solubilizes protein $\mathrm{d}$ and part of proteins III and IV, while proteins $b$ and $c$ and part of proteins III and IV remain associated with the peptidoglycan (Lugtenberg et al., 1977; Hindennach \& Henning, 1975). These peptidoglycan-associated membrane constituents may be precipitated when antibodies to at least one of the composing subunits are present in the antiserum. When such immuno- 


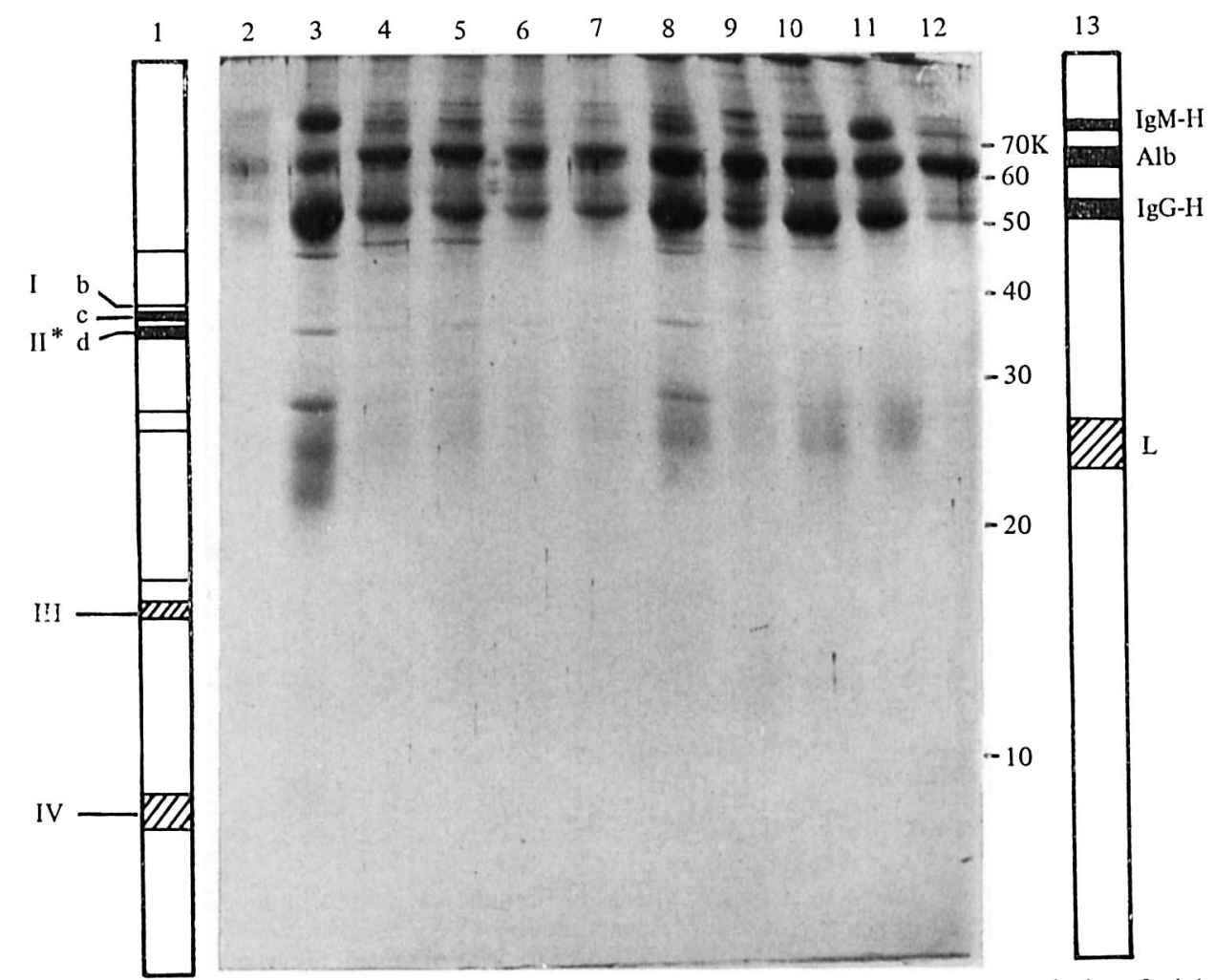

Fig. 3. Polyacrylamide gel electrophoresis patterns of immunoprecipitates obtained in interfacial precipitin tests carried out with antiserum against $E$. coli O26 K60 (absorbed with LPS O26) containing $0.15 \%(\mathrm{w} / \mathrm{v})$ SDS and outer membrane preparations of several Gram-negative bacteria, solubilized by boiling in $2 \%(\mathrm{w} / \mathrm{v})$ SDS, followed by dilution to $0 \cdot 2 \%(\mathrm{w} / \mathrm{v})$ SDS: $E$. coli serotypes O1 K- (2), O26 K60 (3), O111 K58 (4), strain J5 (5), O4 K2 (6), O55 K59 (7), O75 K- (8); Salmonella typhimurium (9); Klebsiella pneumoniae (10); Proteus vulgaris (11); Pseudomonas aeruginosa (12). Control gels (1 and 13) as in Fig. 2.

precipitates are boiled in SDS before PAGE analysis the protein molecules composing the original complex are separated and will then be detected in the PAGE profiles as distinct bands, suggesting that these proteins had participated in the precipitin reaction as individual antigens. Such an explanation may account for some of the apparent anomalies in Fig. 2. For instance, in profiles 6 and 8 the 41000 dalton protein of $E$. coli $\mathrm{O} 4 \mathrm{~K} 2$ and $\mathrm{O} 75 \mathrm{~K}^{-}$was detected in immunoprecipitates obtained with room temperature-solubilized $\mathrm{OM}$ of these serotypes and antiserum against type $\mathrm{O} 26 \mathrm{~K} 60$, although $\mathrm{OM}$ of the latter does not contain this protein (see Fig. 1, track 2). Solubilization of the OM in SDS at $100{ }^{\circ} \mathrm{C}$ separates all the constituent molecules except a part of the lipoprotein (protein IV) which is covalently bound to the peptidoglycan layer (Braun, 1975). The appearance of OM proteins in PAGE profiles of immunoprecipitates obtained after application of boiled $\mathrm{OM}$ to antisera therefore shows the participation of these OM proteins as separate molecules in the formation of immunecomplexes. Under these circumstances most $E$. coli OM proteins in the 33000 to 41000 dalton range were seen in the PAGE profiles of the immunoprecipitates with a strong predominance of protein $d$ over proteins $b$ and $c$ (Fig. 3). This suggests that protein $d$ may be the dominant common surface antigen, particularly since this protein is shared by most strains studied (see Fig. 1). However, the effect of boiling and denaturation by SDS on the antigenicity of the proteins cannot be determined properly, because these drastic methods have to be employed to achieve their separation into single molecules. 


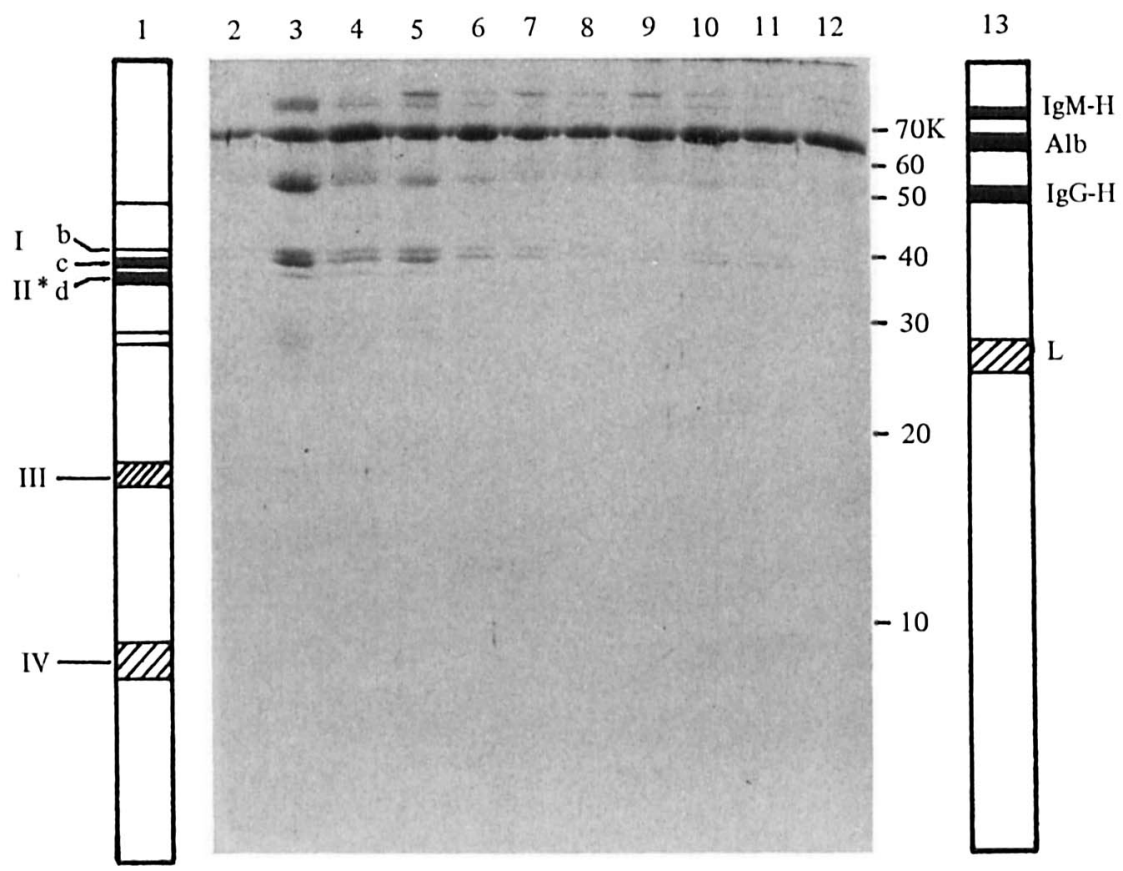

Fig. 4. Polyacrylamide gel electrophoresis patterns of immunoprecipitates obtained in interfacial immunoprecipitin tests carried out with outer membrane preparations of $E$. coli $\mathrm{O} 26 \mathrm{~K} 60$, solubilized in $0.2 \%(\mathrm{w} / \mathrm{v})$ SDS at room temperature, and rabbit antisera containing $0.15 \%(\mathrm{w} / \mathrm{v})$ SDS. Antisera were raised against $E$. coli serotypes $\mathrm{O} 1 \mathrm{~K}^{-}(2), \mathrm{O} 26 \mathrm{~K} 60$ (3), O111 K58 (4), strain J5 (5), O4 K2 (6), O55 K59 (7), O75 K- (8), Salmonella typhimurium (9), Klebsiella pneumoniae (10), Proteus vulgaris (11), Pseudomonas aeruginosa (12). All sera were atsorbed with their appropriate LPS. Control gels (1 and 13) as in Fig. 2.

\section{Polyacrylamide gel electrophoresis of immunecomplexes from E. coli $\mathrm{O} 26 \mathrm{~K} 60$ outer membrane preparations and antisera against Gram-negative bacteria}

Figure 4 shows PAGE profiles of immunoprecipitates formed in the interface between antisera elicited against various bacteria and the $\mathrm{OM}$ of $E$. coli $\mathrm{O} 26 \mathrm{~K} 60$ suspended at room temperature in $0.2 \%(\mathrm{w} / \mathrm{v})$ SDS. The antisera were absorbed with their appropriate LPS; this caused a decrease in bacterial agglutination titres to values below $1: 128$. The amounts of OM proteins found in the immunecomplexes were closely related to the amounts of immunoglobulins. The profile of the immunoprecipitate formed with the antiserum against E. coli $\mathrm{O} 26 \mathrm{~K} 60$ and the OM of the same serotype showed the major OM proteins in the 33000 to 41000 dalton range (Fig. 4, track 3 ). The bands of proteins b and c were much stronger than the protein $\mathrm{d}$ band in this profile. When the OM of E. coli O26 K60 solubilized at room temperature was reacted with antisera against the other strains, proteins $b$ and $\mathrm{c}$ were seen in all profiles, while protein $\mathrm{d}$ was only apparent in the immunecomplexes formed with antisera against some of the $E$. coli serotypes.

The results of similar experiments using $E$. coli $\mathrm{O} 26 \mathrm{~K} 60 \mathrm{OM}$ solubilized at $100{ }^{\circ} \mathrm{C}$ are shown in Fig. 5. The protein pattern of immunoprecipitates from antiserum against $E$. coli O26 K60 and OM of the same serotype (Fig. 5, track 3) showed the major OM proteins in the 33000 to 41000 dalton range and the 16000 dalton protein. In contrast to the results obtained with OM solubilized at room temperature (Fig. 4), the application of boiled OM gave a predominance of protein $d$ compared with proteins $b$ and $c$. Protein $d$ was detected in all profiles except those obtained after application of $K$. pneumoniae, Proteus vulgaris or Pseudomonas aeruginosa antisera (Fig. 5, tracks 10, 11 and 12), while proteins b and c 


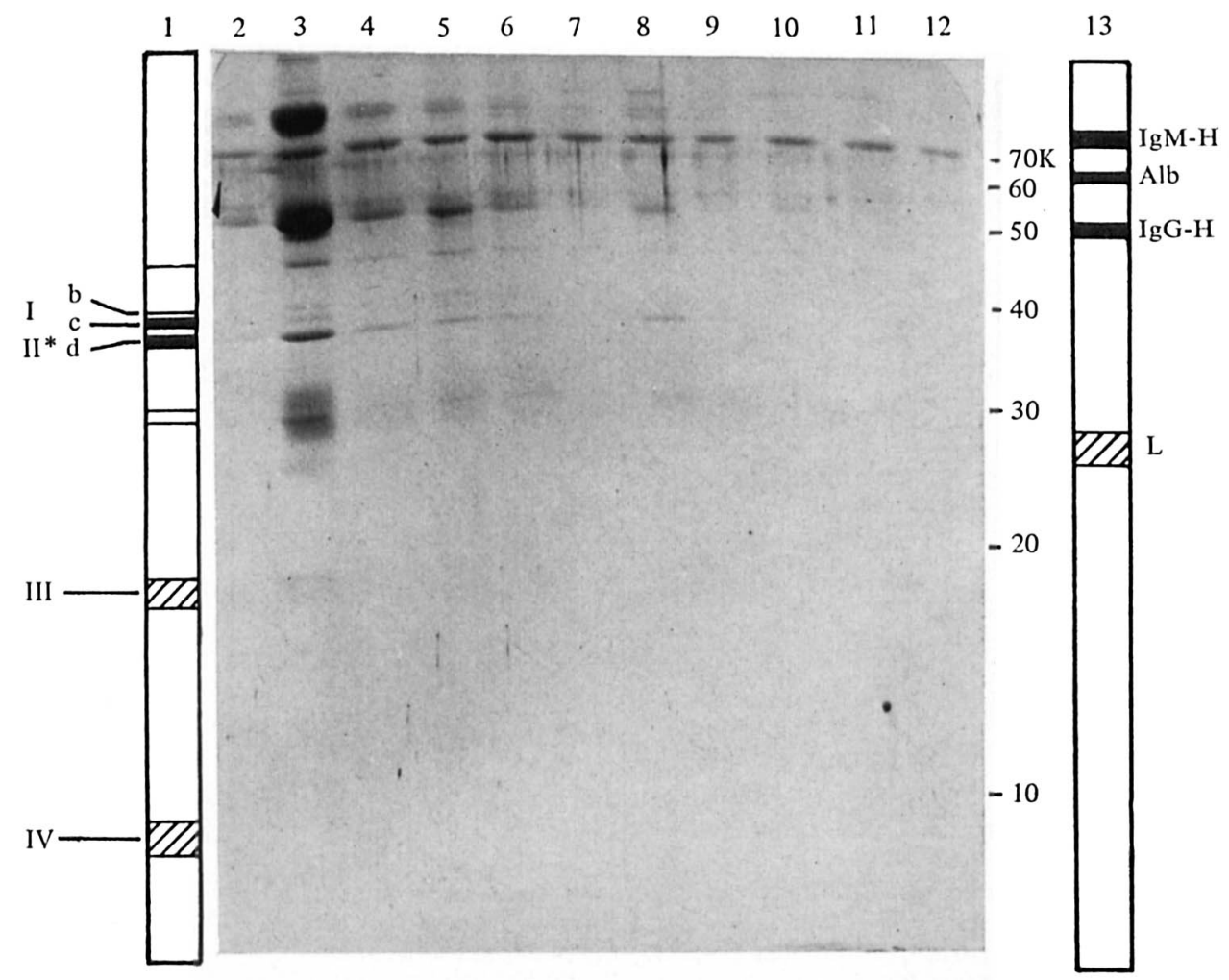

Fig. 5. Polyacrylamide gel electrophoresis patterns of immunoprecipitates obtained in interfacial precipitin tests carried out with outer membrane preparations of $E$. coli $\mathrm{O} 26 \mathrm{~K} 60$, solubilized by boiling in $2 \%(\mathrm{w} / \mathrm{v})$ SDS followed by dilution to $0.2 \%(\mathrm{w} / \mathrm{v}) \mathrm{SDS}$, and rabbit antisera containing $0.15 \%$ (w/v) SDS. Antisera were raised against $E$. coli serotypes O1 K- (2), O26 K60 (3), O111 K58 (4), strain J5 (5), O4 K2 (6), O55 K59 (7), O75 K- (8), Salmonella typhimurium (9), Klebsiella pneumoniae (10), Proteus vulgaris (11), Pseudomonas aeruginosa (12). All sera were absorbed with their appropriate LPS. Control gels (1 and 13) as in Fig. 2.

were only visible in the profiles obtained with some $E$. coli antisera (Fig. 5, tracks 3 to 6 and 8).

From the results shown in Figs 2 and 3 we could only obtain an impression of the degree of cross-reactivity since it was not possible to standardize the amounts of all the antigens applied. However the results shown in Figs 4 and 5 were obtained by reacting equal quantities of $E$. coli $\mathrm{O} 26 \mathrm{~K} 60 \mathrm{OM}$ (solubilized at room temperature or $100^{\circ} \mathrm{C}$ ) with antisera against all bacteria (absorbed with their appropriate LPS). Using room temperaturesolubilized OM of E. coli O26 K60 (Fig. 4), the strongest cross-reactivity was found with E. coli $\mathrm{O} 111 \mathrm{~K} 58$ and its rough mutant J5; these strains closely resemble serotype $\mathrm{O} 26 \mathrm{~K} 60$ in their protein profiles (Fig. 1). Applying boiled OM of E. coli O26 K60 (Fig. 5), a high degree of cross-reactivity was found again with $E$. coli $\mathrm{O} 111 \mathrm{~K} 58$ and $\mathrm{J} 5$ and with serotypes $\mathrm{O} 4 \mathrm{~K} 2$ and $\mathrm{O} 75 \mathrm{~K}^{-}$. Serotype $\mathrm{O} 75 \mathrm{~K}^{-}$- differs markedly from serotype $\mathrm{O} 26 \mathrm{~K} 60$ in its OM profile but both have protein $\mathrm{d}$, which is the major antigen when boiled $\mathrm{OM}$ is applied. The strong cross-reactivity of protein $d$ in these serotypes was also seen when anti-O26 K60 serum was reacted with boiled OM of serotype $075 \mathrm{~K}^{-}$(Fig. 3, track 8). Cross-reactivity was very weak with serotype $01 \mathrm{~K}^{-}$or Pseudomonas aeruginosa. The $\mathrm{OM}$ protein profiles of both these organisms showed little similarity to that of $E$. coli $\mathrm{O} 26 \mathrm{~K} 60$.

To test the significance of our observations, cross-absorptions with OM preparations were carried out to remove cross-reacting antibodies from some of the sera. OM of $E$. coli O26 K60 was used to absorb antisera against E. coli $\mathrm{O} 75 \mathrm{~K}^{-}$and Proteus vulgaris, while 
antiserum against $E$. coli $\mathrm{O} 26 \mathrm{~K} 60$ was absorbed with $E$. coli $\mathrm{O} 1 \mathrm{~K}-\mathrm{OM}$. After the absorption, immunoprecipitation tests were carried out with the original OM preparations (solubilized at room temperature or $100^{\circ} \mathrm{C}$ ). Absorption of anti-E. coli $\mathrm{O} 75 \mathrm{~K}^{-}$serum with $\mathrm{OM}$ of E. coli $\mathrm{O} 26 \mathrm{~K} 60$ removed all reactivity against the $\mathrm{OM}$ of the original serotype, although theoretically antibodies against the 41000 dalton protein should have been left in the serum. Absorption of antiserum against Proteus vulgaris with OM of E. coli O26 K60 removed hardly any of the activity of this serum against its appropriate OM. Finally, absorption with $\mathrm{OM}$ of $E$. coli $\mathrm{O} 1 \mathrm{~K}^{-}$did not affect the activity of anti-E. coli $\mathrm{O} 26 \mathrm{~K} 60$ serum against $\mathrm{OM}$ of this serotype. These results confirmed the general conclusions about cross-reactivity of OM proteins stated above, although the specificity of the absorption was not as high as would have been expected if all OM proteins had acted as independent antigens. For proteins $\mathrm{a}, \mathrm{b}$ and $\mathrm{c}$, in particular, other methods need to be applied in future to achieve a better definition of these proteins as separate antigens.

We would like to thank Mr R. W. Rozeboom for his assistance in part of this study.

\section{REFERENCES}

AMES, G. F. (1974). Resolution of bacterial proteins by polyacrylamide gel electrophoresis on slabs. Membrane, soluble, and periplasmic fractions. Journal of Biological Chemistry 249, 634-644.

Braun, V. (1975). Covalent lipoprotein from the outer membrane of Escherichia coli. Biochimica et biophysica acta 415, 335-377.

Braun, V., Bosch, V., Klumpr, E. R., NefF, I., Mayer, H. \& Schlecht, S. (1976). Antigenic determinants of murein lipoprotein and its exposure at the surface of Enterobacteriaceae. European Journal of Biochemistry 62, 555-566.

Chedid, L., Parant, M., Parant, F. \& Boyer, F. (1968). A proposed mechanism for natural immunity to enterobacterial pathogens. Journal of Immunology 100, 292-301.

CowAN, S. T. \& STEEL, K. J. (1965). Manual for the Identification of Medical Bacteria. Cambridge: Cambridge University Press.

DANKert, J. \& Hofstra, H. (1978). Antibodies against outer membrane proteins in rabbit antisera prepared against Escherichia coli O26 K60. Journal of General Microbiology 104, 311-320.

Ellwood, D. C. (1970). The distribution of 2-keto3-deoxy-octonic acid in bacterial walls. Journal of General Microbiology 60, 373-380.

Galanos, C., Lüderitz, O. \& WestPhal, O. (1971). Preparation and properties of antisera against the lipid-A component of bacterial lipopolysaccharides. European Journal of Biochemistry 24, 116122.

Garten, W., Hindennach, I. \& Henning, U. (1975). The major proteins of the Escherichia coli outer cell envelope membrane. Characterization of proteins II and III, comparison of all proteins. European Journal of Biochemistry 59, 215-221.

Henning, U., Höhn, B. \& Sonntag, I. (1973). Cell envelope and shape of Escherichia coli $\mathrm{K} 12$. The ghost membrane. European Journal of Biochemistry 39, 27-36.

Hindennach, I. \& Henning, U. (1975). The major proteins of the Escherichia coli outer cell envelope membrane. Preparative isolation of all major membrane proteins. European Journal of Biochemistry 59, 207-213.

Kaluser, B. \& Ahlstedt, S. (1977). Protective capacity of antibodies against Escherichia coli $\mathrm{O}$ and $\mathrm{K}$ antigens. Infection and Immunity 17, 286289.

Kunin, C. M., Beard, M. V. \& Halmagyi, E. (1962). Evidence for a common hapten associated with endotoxin fractions of Escherichia coli and other Enterobacteriaceae. Proceedings of the Society for Experimental Biology and Medicine 111, 160-166.

KWAPINSKI, J. B. G. (1972). The precipitation test. In Methodology of Immunochemical and Immunological Research, pp. 317-332. Edited by J. B. G. Kwapinski. New York: John Wiley.

LAEMMLI, U. K. (1970). Cleavage of the structural proteins during the assembly of the head of bacteriophage T4. Nature, London 227, 680-685.

Lowry, O. H., Rosebrough, N. J., FARr, A. L. \& Randall, R. J. (1951). Protein measurement with the Folin phenol reagent. Journal of Biological Chemistry 193, 265-275.

LugtenberG, B., Meyers, J., Peters, R., Van der Hoek, P. \& VAN AlPhen, L. (1975). Electrophoretic resolution of the "Major outer membrane protein' of Escherichia coli K12 into four bands. FEBS Letters 58, 254-258.

Lugtenberg, B., Bronstein, H., Van Selm, N. \& Peters, R. (1977). Peptidoglycan-associated outer membrane proteins in Gram-negative bacteria. Biochimica et biophysica acta 465, 571-578.

Manning, P. A. \& Reeves, P. (1977). Outer membrane protein $3 \mathrm{~B}$ of Escherichia coli $\mathrm{K} 12$ : effects of growth temperature on the amount of the protein and further characterization on acrylamide gels. FEMS Microbiology Letters 1, 275-278.

McCabe, W. R. \& Greely, A. (1973). Common Enterobacterial Antigen. II. Effect of immunization on challenge with heterologous bacilli. Infection and Immunity 7, 386-392.

McCabe, W. R., Bruins, S. C., Craven, D. E. \& JoHNs, M. (1977). Cross-reactive antigens: their 
potential for immunization-induced immunity to Gram-negative bacteria. Journal of Infectious Diseases 136 suppl., S161-S166.

Mullan, N. A., Newsome, P. M., Cunnington, P. G., Palmer, G. H. \& Wilson, M. E. (1974). Protection against Gram-negative infections with antiserum to lipid A from Salmonella minnesota R595. Infection and Immunity 10, 1195-1201.

Neter, E., Kennedy, E. A. \& Jewett, T. C. (1973). Antibody response to common enterobacterial antigen of children with pyogenic peritonitis. Infection 1, 12-16.

NG, A. K., Chen, C. H., Chang, C. M. \& NowotNY, A. (1976). Relationship of structure to function in bacterial endotoxins: serologically crossreactive components and their effect on protection of mice against some Gram-negative infections. Journal of General Microbiology 94, 107-116.

Schnaitman, C. A. (1970). Comparison of the envelope protein compositions of several Gramnegative bacteria. Journal of Bacteriology 104, 1404-1405.

Schnaltman, C. A. (1971). Solubilization of the cytoplasmic membrane of Escherichia coli by
Triton X-100. Journal of Bacteriology 108, 545552.

Tate, W. J., Douglas, H. \& Braude, A. I. (1966). Protection against lethality of Escherichia coli endotoxin with $\mathrm{O}$ antiserum. Annals of the New York Academy of Sciences 133, 746-762.

Vogel, H. J. \& Bonner, D. M. (1956). A convenient growth medium for Escherichia coli and some other microorganisms (Medium E). Microbial Genetics Bulletin 13, 43-44.

WestPhal, O., LüDeritz, O. \& Bister, F. (1952). Über die Extraktion von Bakterien mit PhenolWasser. Zeitschrift für Naturforschung 7b, 148155.

Young, L. S., Stevens, P. \& Ingram, J. (1975). Functional role of antibody against 'core' glycolipid of Enterobacteriaceae. Journal of Clinical Investigation 56, 850-861.

Ziegler, E. J., Douglas, H., Sherman, J. E., Davis, C. E. \& Braude, A. I. (1973). Treatment of $E$. coli and Klebsiella bacteremia in agranulocytic animals with antiserum to a UDP-gal epimerase-deficient mutant. Journal of Immunology 111, 433-438. 